\title{
A FIELD TAKES STOCK: PAPERS FROM THE 8TH INTERNATIONAL CONGRESS ON COASTAL AND MARINE TOURISM
}

\author{
MARC L. MILLER,* JAN AUYONG,† BRIAN W. SZUSTER,‡ MARK D. NEEDHAM,§ \\ MARK B. ORAMS, $₫$ JEFF WILKS,\# AND MICHAEL LÜCK** \\ *School of Marine and Environmental Affairs, University of Washington, Seattle, WA, USA \\ †Oregon Agricultural Experiment Station, Oregon State University, Corvallis, OR, USA \\ ‡Department of Geography, University of Hawaii at Mānoa, Honolulu, HI, USA \\ $\S$ Department of Forest Ecosystems and Society, Oregon State University, Corvallis, OR, USA \\ ISchool of Sport and Recreation, Auckland University of Technology, Auckland, New Zealand \\ \#Griffith Health Institute for the Development of Education and Scholarship, Griffith University, \\ Logan Campus, QLD, Australia \\ **School of Hospitality and Tourism, Auckland University of Technology, Auckland, New Zealand
}

\begin{abstract}
Humans are transforming the coastal and marine tourism environment at an ever-increasing rate. Concurrently, the multiple amenities and natural resources of coastal zones and the reality of population growth contribute to omnipresent tourism user conflicts. This results in social, wicked, and super wicked problems that are value infused, difficult to frame, and seemingly intractable. In response, scientists and other experts are encouraged to engage in use-inspired research. Further, they are advised to reconsider the basic applied science dichotomy and to make policy contributions in the role of the honest broker. Articles from the 8th International Congress on Coastal and Marine Tourism are introduced that deal with tsunami vulnerability (Thailand), wreck diving (Australia/Micronesia), national forest planning (Gulf of Alaska), cruise industry research, aquatic safety (Australia), surfing expansion (South Africa), stakeholder relations (Zanzibar, Tanzania), and kiteboarding (the Netherlands).
\end{abstract}

Key words: Anthropocene; Honest broker; Human dimensions research; Social problems; Use-inspired basic research; Values; Wicked problems

It is perhaps, however, occasionally well to take stock of our mental experience.

-James Anthony Froude, historian, man of letters and Oceanic tourist (1881, p. 19) ${ }^{1}$
The answer, my friend, is blowin' in the wind The answer is blowin' in the wind

-Bob Dylan 


\section{Introduction}

The 8th International Congress on Coastal and Marine Tourism (CMT2015) convened on the Big Island of Hawaii 25 years from the time of the first CMT Congress also held in Hawaii. The eventand its theme "Learning From the Past, Looking to the Future"-provided a timely and fitting opportunity for delegates to celebrate and constructively ponder the record of focused coastal and marine tourism research. ${ }^{2}$

In organized sessions and informal discussions, delegates reported findings, offered recommendations and advice, and exchanged insights and ideas. At the same time, they could not help but evaluate the condition and future of the field. In taking stock of achievements and missed opportunities delegates realized that the research agenda for the next quarter century should be driven not only by unconstrained scientific curiosity, but also by a responsibility to make for a better world.

Although no formal programmatic, scientific, or moral consensus emerged at CMT2015, several concepts surfaced that have promise for setting future research agendas:

1. Sustainable policies and projects shaping coastal and marine tourism depend on the consideration of value conflicts as much as on the study of natural patterns.

2. There are more questions than answers, although some questions may be better than others.

3. Humans, their artifacts and technologies, and nature are inextricably interconnected in a single complex system.

4. Both the natural and social sciences are necessary for understanding the dynamics of coastal and marine tourism, but they are not sufficient. Expertise in human dimensions involving the social sciences and the applied humanities (e.g., environmental history and philosophy, ethnic studies) and professional fields (e.g., communication, education, law, conflict resolution/mediation, political activism) have much to offer in this regard. ${ }^{3}$

5. Although change is a fact of life, things change at different scales and rates.

For these propositions to be useful and not merely homilies, they must be carefully and strategically linked to coastal and marine tourism issues. A few remarks follow about the nature of problems and the roles available to coastal and marine tourism researchers and practitioners who are dedicated to resolving these issues.

\section{The Anthropocenic Context of Coastal and Marine Tourism}

Geologists label the present epoch as the Anthropocene in recognition of the extraordinary influence of the human species on the natural world. Throughout the Anthropocene, change-whether measured against cultural, political, ecological, technological, institutional, among a diversity of standards-has transformed life on Earth in both gradual and dramatic ways. Although the responsibility of humans for many fundamental and revolutionary changes in society has always been obvious, the responsibility of humanity for causing and addressing environmental change has been hotly debated. Insofar as coastal and marine tourism is concerned, it is a truism that societal and environmental aspects of this tourism are increasingly subject to intense pressures of humanity.

Today, it is increasingly the case that the general public, as well as the scientific community and practitioners, realize the potency of society in determining the condition of the environment. Geologists have accepted that the Anthropocene is a new geological epoch succeeding the Holocene (that began roughly 11,700 years ago) and which is marked by significant anthropogenic changes to the Earth's climate, oceans, land, and biosphere (Ellis, 2011; Tyrrell, 2011; Zalasiewicz, Williams, Haywood, \& Ellis, 2011).

There is as yet no agreement about when to date the beginning of the Anthropocene. Waters et al. (2016) noted that:

Proposals for the start of the Anthropocene have included 1) an "early Anthropocene" associated advent of agriculture, animal domestication, extensive deforestation, and gradual increases in atmospheric carbon dioxide (CO2) and methane (CH4) thousands of years ago, 2) the Colombian Exchange of Old World and New World species associated with colonization of the Americas, 3) the beginning of the Industrial Revolution at $\approx 1800 \mathrm{CE}$, and 4) the mid-20th century "Great 
Acceleration” of Population Growth, industrialization, and mineral and energy use. (p. 137)

Of these proposals, the most specific is that of Zalasiewicz et al. (2015) who linked the beginning of the Anthropocene to "the time of the world's first nuclear bomb explosion on July 16, 1945 at Alamogordo, New Mexico” (p. 196).

An explicit awareness that modern life takes place in the Anthropocene is gaining widening acceptance in academia. Scholars and scientists in a range of disciplines are beginning to call for adjustments in the questions asked, and the goals pursued in research. To illustrate, environmental sociologist Manuel Arias-Maldonado (2016) has remarked on the future of sustainable studies in the Anthropocenic context. Additionally, geographer Simon Dalby (2016) has argued that political ecology and geopolitics will be (and should be) shaped by the Anthropocene: "How the Anthropocene is interpreted, and who gets to invoke which framing of the new human age, matters greatly both for the planet and for particular parts of humanity” (p. 33).

\section{An Embarrassment of Problems}

Over the ages, people have-by taking advantage of human curiosity, serendipity, opportunity, and tools and technologies—solved problems through innovation. Many of these problems, such as those that are technologically framed and that have concerned basic needs and idiosyncratic wants, have been resolved without controversy. Similarly, there are many examples of religious doctrines, statutes, and regulations that have long histories and have been implemented without conflict. However, the historical record is also replete with instances in which people have challenged the problems addressed by others, as well as solutions proposed or realized.

\section{Social Problems}

In the 1940s, sociologists Richard C. Fuller and Richard R. Myers pioneered the field of social problems to foster understandings of problems that have no simple technological, logical, or moral fix, and are characterized by conflicts among people with different values:

\begin{abstract}
A social problem is a condition which is defined by a considerable number of persons as a deviation from some social norm which they cherish. Every social problem thus consists of an objective condition and a subjective definition. The objective condition is a verifiable situation which can be checked as to existence and magnitude (proportions) by impartial and trained observers. ... The subjective definition is the awareness of certain individuals that the condition is a threat to cherished values. . . . In the last analysis, social problems arise and are sustained because people do not share the same common values and objectives.
\end{abstract}

Social problems do arise full-blown, commanding community attention and evoking adequate policies and machinery for their solution. On the contrary, we believe that social problems exhibit a temporal course of development in which different phases or stages can be distinguished. Each stage anticipates its successor in time and each succeeding stage contains new elements which mark it off from its predecessor. A social problem thus conceived as always being in a dynamic state of "becoming" passes through the natural history stages of awareness, policy determination, and reform (Fuller \& Myers, 1941, pp. 320-321, emphasis added). ${ }^{4}$

\section{Tourism Problems}

With the above in mind, tourism problems are of two kinds. Some are not social problems as they are not contested by any constituency and can be solved with the conventional tools of public administration and government (e.g., laws and regulations, permits, zoning). Others clearly qualify as social problems because constituencies clash over what values ought to be respected or protected, and how values ought to be prioritized.

Tourism problems that are social problems are as old as tourism. One example traces to the Ancient Roman Empire. During the rule of Emperor Trajan (reign 98-117 CE), Pliny the Younger (61-113 CE) wrote to his literary friend, wealthy landowner Caninius Rufus, about "a true story which sounds very like fable" that he had heard over the dinner table. Pliny thought the story might provide inspiration for a poem (Pliny the Younger, 1969, p. 145).

The account concerns touristic pressure on the Roman colony of Hippo Diarrhytus (today Bizerta) situated on the coast northwest of Carthage (now Tunisia) and near a navigable lagoon connected 
to the sea. Pliny the Younger (1969) reported that: "People of all ages spend their time here to enjoy the pleasures of fishing, boating, and swimming, especially the boys who have plenty of time to play" (p. 254).

At the shore, a boy swam out to deep water and with time developed a relationship with a dolphin who played with him and allowed him to ride on his back. The boy "believed it knew him and loved him and he loved it." Crowds of locals came to the shore to witness the spectacle. Townspeople considered the boy a prodigy and they too were able to play with and touch the dolphin. On one occasion, the governor "was moved by some misguided superstition to pour scented oil on the dolphin while it lay on the shore" and this caused the dolphin to avoid the town for a few days (Pliny the Younger, 1969, p. 255).

The fame of the dolphin spread throughout the region and it became a tourist attraction. Ultimately, this led to a social problem that was resolved in a most unfortunate way:

All the local officials used to gather to see the sight, and their arrival to stay in the little town began to burden it with extra expense, until finally the place itself was losing its character of peace and quiet. It was decided then that the object of the public's interest should be quietly destroyed. (Pliny the Younger, 1969, p. 255). ${ }^{5}$

It should be emphasized that problems, notwithstanding how they are commonly named or labeled, fall under the umbrella of social problems when they reveal value conflicts. To illustrate, projects and policies of sustainable development, globalization, poverty, war, pestilence, diaspora/relocation, climate change, neocolonialism, sea level rise and natural disaster relief, tourism development, natural resource and ecosystem resilience/vulnerability and management, biodiversity loss, endangered species protection, social/environmental justice, and immigration control are but a few of the contemporary issues that can be analyzed as social problems.

\section{Wicked Problems}

In the 1960s, several professors at the University of California at Berkeley (UCB) realized that many problems they found to be especially intractable and vexing were, in fact, social problems. They also observed that the human dimensions of these problems were undervalued by researchers.

Horst Rittel, a Professor of the Science of Design in the Department of Architecture at UCB, attended a weekly seminar focused on how space program technologies might be applied to urban problems. At the event, he remarked on the ill-defined problems of architectural and urban planning and presented 10 attributes that distinguish social from scientific or technical problems (Skaburskis, 2008; Table 1). The first of these clarified that research design for the study of "wicked problems" is anything but straightforward:

There is no definite formulation of the problem. The problem includes a permanent feedback with

Table 1

The Attributes of Wicked Problems

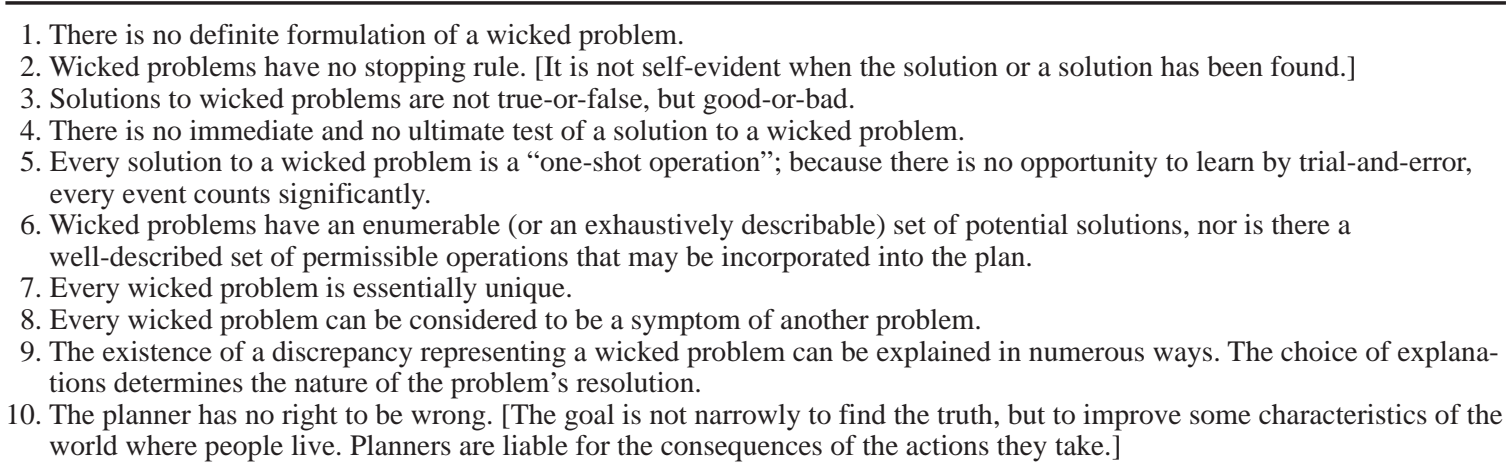


its environment. The process of formulating the problem is interconnected with the process of its solution. To ask all the relevant questions to gain information on the problem, you must know all the conceivable alternative solutions. (Lecture by Horst Rittel, October 12, 1967, Berkeley, cited in Skaburskis, 2008, p. 278)

C. West Churchman, a philosopher and systems scientist at the UCB, attended Rittel's seminar. Churchman had a solid background in logic and formal science, statistics, operations research, and management science, but now wanted to understand the role of ethical values in science applications.

In a famous guest editorial of Management Science, Churchman was the first to publish on wicked problems. However, he was clear about his debt to Rittel:

Professor Horst Rittel has suggested in a recent seminar that the term "wicked problem" refer to that class of social system problems which are illformulated, where the information is confusing, where there are many clients and decision makers with conflicting values, and where the ramifications in the whole system are thoroughly confusing. The term "wicked” is supposed to describe the mischievous and even evil quality of these problems, where proposed "solutions" often turn out to be worse than the symptoms. (Churchman, 1967, p. B-141). ${ }^{6}$

Churchman's editorial was short, but it was extrainfluential for generalizing the application of the wicked problems concept well beyond urban and architectural planning. Churchman challenged operations research and management scientists to (a) reflect on how their completed analyses only partially address wicked problems, and (b) communicate frankly about what was not yet analyzed to the clients of research. This was offered in a positive way:

What seems to emerge is not a moral reprimand of the management scientist, but rather a moral problem of the profession, a wicked moral problem. To what extent are we morally responsible to inform the manager in what respect our "solutions" have failed to tame his wicked problems? Does "inform" merely mean that we clear ourselves legally, or does it mean that we attempt to enter into a deep, mutual understanding of the untamed aspects of the problem? (Churchman, 1967, p. B-142)
Churchman's 1967 editorial, and the urging of colleague and city planner Max Webber, led Rittel to collaborate with Webber in a classic article in Policy Sciences (Rittel \& Webber, 1973; see also, Skaburskis, 2008). In this, the authors expanded from architectural and urban planning examples to argue planning is an essential means to success in a wide variety of professions. In introducing a general theory of planning, Rittel and Webber articulated that wicked problems are social problems of governance and the professionals who deal with these problems include planners, practitioners of scientific management, systems analysts, and many managers in the public and private sectors:

The kinds of problems that planners deal withsocietal problems - are inherently different from the problems that scientists and perhaps some classes of engineers deal with. As distinguished from problems in the natural sciences, which are definable and separable and may have solutions that are findable, the problems of governmental planning are ill-defined; and they rely upon elusive political judgement for resolution. (Not "solution." Social problems are never solved. At best they are only re-solved-over and over again). (Rittel \& Webber, 1973, p. 160)

Rittel and Webber elaborated on the 10 distinguishing features of wicked problems Rittel had presented in seminar years before. ${ }^{7}$ These are summarized in Table 1.

In the time since these two articles, wicked problems have come to command the attention of a wide range of researchers in the applied social sciences and professional disciplines. Although there is as yet no Journal of Wicked Problems, nor a Society for the Study of Wicked Problems, the concept certainly has witnessed wide application.

The following sample of studies confirms there is no single disciplinary approach to identifying, framing, and taming wicked problems. Although a subset of these studies addresses tourism issues, not all of these wicked problems in tourism and recreation take place in coastal settings. Nonetheless, the analytical approaches, concepts, and methodologies employed in these and the other nontourism studies provide inspirational templates for coastal and marine tourism research in the future: ${ }^{8}$ Illustrative articles for various types of studies are included below. 
- Tourism and recreation (Brooks \& Champ, 2006; D’Angella \& Go, 2009; Desmond, 2016; Farasi, Butler, \& Szivas, 2011; Odeh, 2010; Ogulin, Selen, \& Houghton, 2016; Scherrer \& Doohan, 2014; Schweinsberg, Darcy, \& Cheng, 2017; Shannon, Oncescu, \& Hutchinson, 2016; Strickland-Munroe, Allison, \& Moore, 2010; Tribe \& Liburd, 2016);

- Ecosystems, natural resources, forestry, agriculture (Allen \& Gould, 1986; DeFries \& Nagendra, 2017; Shindler, 1999; Whyte \& Thompson, 2012);

- Socioecological systems (Bruggemann, et al., 2012; Xiang, 2013); and

- Policy, business, planning, design thinking, sustainability, management, and organization studies (Buchanan, 1992; Charbonneau, 2012; Durant \& Legge, 2006; Grint, 2008; Head, 2008; Ritchey, 2013; Rittel, 1972; Waddock, 2013; Zellner \& Campbell, 2015).

\section{Super Wicked Problems}

Without question, among the most dramatic and pressing of wicked problems are those that are driven by climate change (FitzGibbon \& Mensah, 2012; Moser, Jeffress Williams, \& Boesch, 2012; Van Epp \& Garside, 2016). Indeed, these problems, because of their extreme complexity and omnipresence, influence all coastal and marine tourism.

In 2007, Levine and colleagues drew from the work of Rittel and Webber (1973), and first described global climate change as a "super wicked problem” in a paper presented at an International Studies Association annual convention; a few years later, these authors published the article describing climate change as falling in a new class of environmental problems (Levine, Cashore, Bernstein, \& Auld, 2012; see also Adams-Shoen, 2015; Lazarus, 2009):

Super wicked problems comprise four key features:

1. Time is running out.

2. Those who cause the problem also seek to provide a solution.

3. The central authority to address them is weak or nonexistent.

4. Irrational discounting occurs that pushes responses into the future.
Together, these features create a tragedy because our governance institutions, and the policies they generate (or fail to generate), largely respond to short-term time horizons even when the catastrophic implications of doing so are far greater than any real or perceived benefits of inaction. (Levine et al., 2012, p. 124)

In addition, with super wicked problems those who bear the costs or suffer most from the problem are not those who cause the problem or have the ability to develop a solution to address it. This is certainly the case for climate change where the peoples of Kiribati, Tuvalu, the Maldives, and coastal Bangladesh are not the cause of the problem, but will certainly face the dramatic consequences in the very near future.

\section{Science, Values, Advocacy, and Policy}

Many of the world's great cities and most heavily visited touristic destinations are in the coastal zone, and a great number of these are threatened by climate change, especially as manifest in sea level rise and the intensification, if not frequency, of hurricanes, heavy rainfall, and tidal surges. As policymakers and leaders of industry, especially in the US, struggle to adapt to climate change, they have found that significant portions of the general public are expressing concerns over the very validity of science.

This general situation is exacerbated when the talents and responsibilities of applied and basic scientists and other experts, special interest advocates, practitioners, and policymakers are blurred. To illustrate, it is commonplace for a policymaker to ask a scientist: "Which of these policy alternatives should be adopted?” The cleanest of answers, of course, would be:

Well, we know from our results that Option 1 will have a particular consequence, and Options 2 and 3 will have others that we can specify. Your selection among these options will depend on your values and those of stakeholders you hold in high regard. $^{9}$

Applied scientists are taught they can use science to inform policymakers about what is, but they cannot rely on science to influence policymakers as to what should be. And, scientists are often taught 
to refrain from supplementing their scientifically derived results with their personal opinions or advocacy positions regarding the "best" policy option.

There was at time in which science seemed to be of two kinds (a) basic science where truth was pursued for its own sake, and (b) applied science where usefulness of results for a client was a key factor in research design. Now, this binary distinction is regarded as simplistic, if not seriously misleading. As will be seen, the work of two political scientists who have studied (super) wicked environmental and climate change problems is informative and didactic in this regard.

\section{Pasteur's Quadrant}

William C. Clark—an ecologist, environmental policy analyst and Associate Editor of the Proceedings of the National Academy of Sciences-has written that the relatively new field of sustainability science is committed to "practical protections for the Earth's key life-support systems” (Clark, 2007, p. 1737):

From its core focus on advancing understanding of coupled human-environmental systems, sustainability science has reached out with focused problemsolving efforts targeted to urgent human needs.

Sustainability science is thus most usefully thought of as neither "basic" nor "applied" research. Rather, it is an enterprise centered on the "use-inspired basic research" that the late Donald Stokes characterized as "Pasteur's Quadrant" of the modern science and technology enterprise. (Clark, 2007, p. 1737)

In contrasting the styles of prominent scientific figures, political scientist Donald Stokes has argued that Louis Pasteur epitomized a researcher who explicitly tailored his research agenda to solving a problem in his lifetime (Fig. 1).

\section{Honest Brokers}

Roger A. Pielke-a political scientist renowned for his insights on climate change politicsdeveloped a typology in The Honest Broker: Making Sense of Science in Policy in Politics (2007) of four idealized roles available for scientists (and experts more generally) who would participate in the policymaking arena (Fig. 2).

The horizontal dimension in Figure 2 contrasts two views of the role of science in society as held by scientists, experts, and potential advisors. With the linear model, basic research inspires applied research and development and, ultimately, societal benefits. In some instances, there is agreement that scientific knowledge is a prerequisite for political consensus and policy actions. The stakeholder model emphasizes that: "the users of science should have some role in its production but that considerations of how science is used in decision-making

\section{RELEVANCE}

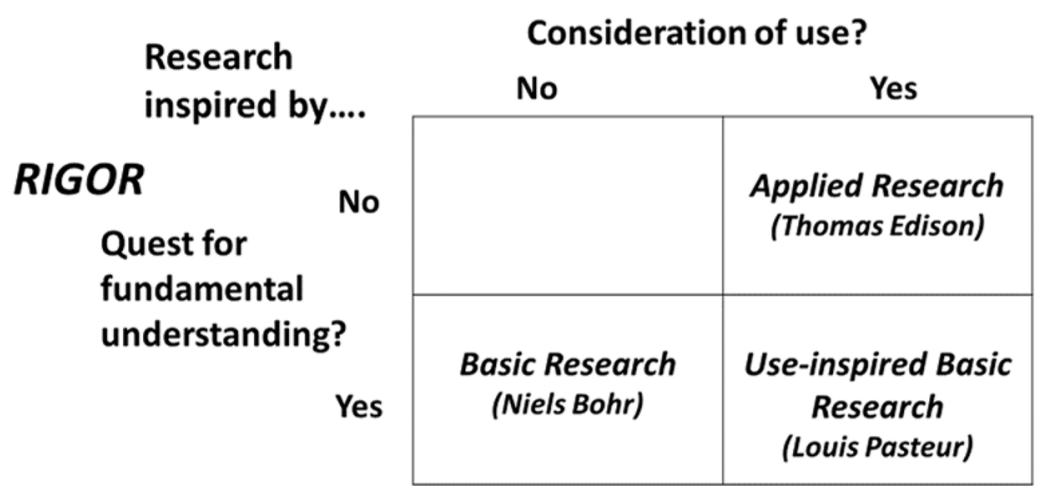

Figure 1. Types of research. Adapted from Pasteur's Quadrant (Stokes, 1997, p. 73) and Clark (2007, p. 1737). 


\begin{tabular}{c|c|c|}
\multicolumn{1}{c}{$\begin{array}{c}\text { VIEW OF } \\
\text { VIEMOCRACY }\end{array}$} & $\begin{array}{c}\text { Linear } \\
\text { Model }\end{array}$ & $\begin{array}{c}\text { SCIENCE IN SOCIETY } \\
\text { Stakeholder } \\
\text { Model }\end{array}$ \\
\cline { 2 - 3 } $\begin{array}{c}\text { Interest Group } \\
\text { Pluralism }\end{array}$ & Pure Scientist & $\begin{array}{c}\text { Issue Advocate } \\
\text { Elite Conflict }\end{array}$ \\
\cline { 2 - 3 } & Science Arbiter & $\begin{array}{c}\text { Honest Broker of } \\
\text { Policy Alternatives }\end{array}$ \\
\hline
\end{tabular}

Figure 2. Four modes of science engagement. Adapted from Pielke, (2007, 2015, p. 136). See also Jasanoff (2008, p. 240).

are an important aspect of understanding the effectiveness of science in decision-making” (Pielke, 2007, p. 14).

The vertical dimension in Figure 2 contrasts two views of the democratic process held by potential advisors. With the interest group pluralism perspective, experts serve society by cooperating and aligning with whatever faction or interest group they favor and offering their special analyses and advice. Moreover, "it is a virtue for scientists to take a more proactive role as advocates in political debates seeking to use their authority and expertise as resources in political battles” (Pielke, 2007, p. 12).

With elite conflict perspective, the contribution of scientific advice is highly prioritized. It is the experts' role: "to clarify the implications of their knowledge for action and to provide such implications in the form of policy alternatives to decision-makers who can then decide among different possible courses of action” (Pielke, 2007, p. 12). ${ }^{10}$

With this typology of roles:

- The Pure Scientist is dedicated exclusively to research that is designed with no consideration whatsoever to the utility of results for society. Accordingly, the Pure Scientist has and seeks no connection to the policymaking world.

- The Issue Advocate designs research expressly oriented to the needs of a particular constituency or client. In presenting results to a policymaker, the Issue Advocate makes it clear that she or he is aligned with a special interest group. Accordingly, the Issue Advocate argues openly for the superiority of one policy option over others.

- The Science Arbiter designs research that is reactive and responds to high priority questions as perceived by policymakers. The Science Arbiter makes comparisons between policy options, but stops short of making a recommendation for a preferred policy.

- The Honest Broker designs research that condenses the number of factors that are to be considered by policymakers.

- As Pielke (2007) noted:

The defining characteristic of the honest broker of policy alternatives is an effort to expand (or at least clarify) the scope of choice for decision-making in a way that allows for the decision-maker to reduce choice based on his or her own preferences or values. (pp. 2-3)

Of course-and given the title of his bookPielke saw the Honest Broker as critically important, indeed vital, to the encouragement and legitimation of the input of scientists in the policy process. He made it clear that each of the four roles has merit and that scientists should choose among them to find the role that fits the situation. Perhaps to the surprise of some, Pielke did not attack the Issue Advocate for linking his or her values with results: 
Issue advocacy is fundamental to a healthy democracy and is a noble calling. Advocacy among scientists is often viewed pejoratively, but I don't think it necessarily has to be. Scientists are citizens and as experts have an important role to play in public debates. (Pielke, 2015)

This said, Pielke warns those in the policy arena that some scientists, whether intentionally or not, play a fifth role as Stealth Issue Advocate that definitely has negative consequences that impede both the development of responsible policies and the advancement of applied science:

Stealth issue advocacy refers to situations in which one claims to be serving as a Pure Scientist or Science Arbiter, but instead is focused on reducing the scope of choice available to decision-makers, which is the defining characteristic of an Issue Advocate. (Pielke, 2007, p. 94)

\section{Articles in This Special Double Issue}

The 8th International Congress on Coastal and Marine Tourism (November 10-13, 2015) brought together tourism researchers, policymakers, industry leaders, educators, practitioners, representatives of nongovernmental and other civil society organizations, and both undergraduate and graduate students from around the world. Congress sessions were organized to address a number of overarching topics including community resilience, fishing communities, tourist motivations, visitation use patterns, climate change, environmental impacts, destination images, economic and nonmarket impacts, interpretation and education, marine protected areas, whale watching, shark tourism, and coastal and marine planning. ${ }^{11}$ In addition, delegates participated in workshops and attended poster sessions and a keynote address.

In introducing eight of the best articles presented at CMT2015, these articles (with, perhaps an exception or two) do not specifically identify their tourism issues of interest as social, wicked, or super wicked problems. However, it should not be difficult for the reader to see that these concepts are relevant to the discussion. Readers should be encouraged to think about the depth and scope of problems described in these articles, as well as the extent that solutions are presented as feasible or requiring broader study. With the role of the Honest
Broker in mind, readers are urged to read between the lines about the roles these authors play in communicating results of their research to policymakers. Authors were asked in preparing their articles to comment informally and personally in a final "Learning from the Past, Looking to the Future" section how approaches to their topic might be organized in future research.

\section{Tsunami Disaster Risk and Vulnerability in Coastal Tourism Community: The Case of Khao Lak Area, Thailand (Somrudee Meprasert Jitpraphai, Narumon Arunotai, and Ajira Tiangtrong)}

The southwestern coastline of Thailand is particularly attractive to international tourists for its naturalness. Tourist amenities include numerous and intact beach forest areas, pristine rainforests, waterfalls, and several national parks. Beginning in the late 1980s, development intensified in the Khao Lak region and this led to improvements in infrastructure and tourist services. A sustainable tourism agenda must address the reality that the area is especially vulnerable to tsunamis, as well as beach and soil erosion.

With the realization that "tsunami vulnerability is a multifaceted problem" Jitpraphai and her coauthors selected an approach in which Integrated Coastal Zone Management figures as the key foundation underlying applications of the Precautionary Principle and Science-Management Integration. A model of disaster risk and vulnerability assessment was conducted with geographic information system (GIS) and mapping tools that utilize spatial and nonspatial data. The resulting maps reflect both physical and socioeconomic features of the area. Importantly, these maps serve a vital policymaking and educational need. The maps are audience friendly and are easily understood by planners, scientists, other analysts, and members of local communities who are directly affected by tsunamis.

\section{Human Dimensions of Wreck Diving and Management: Case Studies From Australia and Micronesia (Joanne Edney)}

In the time since the 1980s, recreational scuba diving has flourished as divers have trekked to the 
far corners of the globe to experience the diversity and beauty found in the world's oceans. One expanding sector of the dive industry serves divers intent on seeing historical, military, commercial, and other shipwrecks. Indeed, and as the author points out, "shipwrecks are beautiful, mysterious, and evocative.”

This article provides a needed review of the wreck-diving literature, and in this discusses both the positive and negative impacts of diving on the wrecks and the environment. This article is equally valuable for reporting questionnaire results of Edney's studies of the divers themselves in Australia and in Chuuk Lagoon (Federated States of Micronesia). Findings reveal diver characteristics (i.e., demographics, dive experience, motivations, preferences, attitudes). Insofar as implications are concerned, the author elaborates how this social and behavioral information about divers can be used by managers to maintain the quality of wreckdiving sites and the wreck-diving experience.

\section{Social and Environmental Sustainability in} Large-Scale Coastal Zones: Taking an IssueBased Approach to the Implementation of the Prince William Sound Sustainable Human Use Framework (Dale J. Blahna, Aaron Poe, Courtney Brown, Clare M. Ryan, and H. Randy Gimblett)

The mission of the United States Forest Service is to use the best science available to sustain the health, diversity, and productivity of this country's 154 national forests and 20 grass lands. Established during the Progressive Era in 1905, the Forest Service has a long and distinguished record of managing national forests for multiple-use objectives.

In this study of the Chugach National Forest in the Gulf of Alaska, Blahna and his collaborators are cognizant of the fact that "sustainability is inherently a wicked problem” requiring multidisciplinary attention. In contrast to standard top-down rational planning, this article introduces a practical, issue-based, and ground-up planning approach to management and monitoring strategies for protecting "keystone" recreational experience, as well as social and ecological values. This creative four-step approach stands to have wide application in coastal and marine protected areas where goals of conservation must be balanced with those of human uses, such as recreation and tourism.

\section{Adrift at Sea: The State of Research on Cruise Tourism and the International Cruise Industry (Ross A. Klein)}

Cruise ships-along with merchant marine and naval ships, monasteries, prisons, and some enclave resort enclaves - are prime examples of what sociologists term "total institutions." The social order aboard cruise ships is governed by an authority structure that operates with great autonomy at a geographical distance from its terrestrial counterparts. The contemporary international cruise ship industry is a descendent of the great ocean liners that carried high society and immigrants to foreign shores between the two World Wars. Since the 1970s, the industry has diversified in response to a demand by budget and luxury passengers for shorter vacations. Cruise ships come in many sizes and they offer a rich menu of destination and activity options.

The author is an expert on the cruise ship industry. Klein draws on his own considerable experience studying cruise ship sociology and labor relations to provide an examination and a critique of research on cruise ships. He notes that "the limited and sporadic attention given to the cruise ship industry by academics and nonacademics alike can be explained in part by the 'newness' of cruise tourism." Klein reports that the overwhelming majority of articles on the industry are "performative" in nature, designed to answer technical and practical questions pertaining to the improvement of vessel efficiency and the maximization of profit. His article is a direct call for a different kind of research that is "emancipatory" and designed to critically analyze the industry with a view toward understanding management's exploitative relationships with labor and ports, industry practices that have environmental impacts, and problems of sexual assault and other crimes committed at sea. Klein's discussion of impediments to research on the cruise industry is balanced with suggestions about how future emancipatory research might be organized.

\section{Tourism and Aquatic Safety: No Lifeguard on Duty-Swim at Your Own Risk (Jeff Wilks)}

Tourists and local residents can differ substantially. Comparatively speaking, residents share a familiarity with their place of work and play, 
whereas tourists lack knowledge of local history, the contemporary cultural and social scene, the political and economic climate, and local laws and regulations. One of the pleasures of travel is that this difference creates a condition in which tourists and residents can expand their horizons and learn from one another. But, tourists are also often found to be more vulnerable and at risk than are residents when tourism and recreational activities take place in natural settings that can pose danger. Tourist (and resident) vulnerabilities to other people and to activities that take special skills are anticipated by the best of tourists and those who provide tourism services.

Unfortunately, some tourism activities do not register with the general and traveling public as dangerous. Swimming is a case in point. This article flags aquatic safety as a pressing and understudied problem in the coastal and marine tourism literature. Wilks discusses the vulnerability of tourists when they enter strange waters unprepared and undertrained. The article reviews the legal responsibilities of local government, hotels, resorts, tour operators, and leisure businesses. Wilks provides international examples of lifeguard qualification standards, training, and practices. He promotes a new understanding for the tourism industry and researchers alike- "Going forward, we should see safety not as a negative but rather a key feature of quality customer service.”

\section{From Fringe to Core: Contemplating Surfing's Potential Contribution to Sustainable Tourism Development in South Africa (Jacques D. Mahler-Coetzee)}

The history of surfing is one of cross-cultural diffusion and, very likely, independent invention. Surfing in Hawaii was first described in 1879 by Joseph Banks, the official botanist of Captain James Cook's expedition on the HMS Endeavor. Surfing at that time was an activity reserved for Hawaiian royalty (Ali'i ). Much later in the 1960s, “The Sport of Kings" was taken up by middle-class youth in Australia, New Zealand, and California. In the last quarter century, surfing has diffused throughout the Americas and Europe as well.

In this article, Mahler-Coetzee contemplates the importance of surfing for Africa, focusing on the
South African experience. Surfing in South Africa in its premillennium period (1919-1999) was an expressive form of travel practiced at the fringes of society. However, in the postmillennium period surfing symbols have moved far from the coastal zone and now permeate mainstream society. MahlerCoetzee documents the rise of "new surfing" as reflected in its popularization in surfing contests, and the commodification of its icons in gear, fashion, and film. In his discussion, he considers the positive and negative consequences of the spread of the "surfing ethos," surfing expansion in civil society, and "surf rage" among other issues and challenges. That surfing has real policy significance for the African Union in the development of a blue economy for the entire continent is signaled by the fact that surfing is identified as a tourism development vector in the 2050 Africa Integrated Maritime Strategy.

\section{The Impact of Stakeholder Relations on the Mnemba Island Marine Conservation Area, Zanzibar, Tanzania (Christopher Burgoyne, Clare Kelso, and Kevin Mearns)}

The concept of a protected area implies that nature and/or cultural heritage in a demarcated space is worthy of being immunized from the full impact of anthropogenic forces. The International Union for Conservation of Nature (IUCN) has developed a continuum along which protected areas fall into seven categories ranging from Strict Nature Preserve to Managed Resource Protected Area according to the degree that goals support different intensities and types of human activities.

Today, there are nearly 5,000 marine protected areas (MPAs) of many kinds worldwide. A continuing communication problem for managers and the publics they serve is that the official designation of an MPA (e.g., marine park, marine conservation area, marine reserve, sanctuary) does not always match human activities (e.g., fishing, scuba diving and snorkeling, whale watching) that are permitted or encouraged.

The Mnemba Island Marine Conservation Area (MIMCA) in the Zanzibar Archipelago is known for its beauty, habitat, and biological diversity (e.g., reef fish, corals, whales, whale sharks, dolphins, sea turtles, shorebirds). In this article, Burgoyne 
and his coauthors describe a "community-based" MPA managed for conservation, community livelihood, and tourism goals. MIMCA was created by a cooperative process bringing together the Zanzibar Government and Department of Fisheries, residents of local fishing villages, and the owners of Mnemba Island (and its exclusive Mnemba Island Lodge). In examining stakeholder relations, these authors focus on the importance of social variables (e.g., open communication, transparency, trust) for responsible management and for resolving conflicts and other problems.

\section{Insights for Coastal Destination \\ Development: The Practices of Kiteboarders in the Netherlands (Timo Derriks)}

It may be a truism of business that "if you build it, they will come," but it is also true that people will not come back if they are dissatisfied with their experience. The more that is known about customers and clients, the more easily they can be pleased. These points are certainly in the minds of tourism developers and promoters in the Netherlands who seek to expand health and water sport destinations along the coasts.

With an eye to informing local governments and elements of the tourism industry in the province of Zeeland about a new opportunity, Derriks reports on the practices, motivations, and values of people who engage in the relatively young sport of kiteboarding. Employing a sociological framework known as "practice theory," Derriks describes how a kiteboarding session can be understood as having three phases concerning preparation, the experience on the water, and evaluation. Methods used in this study include interviews and focus groups with kiteboarders and kiteboarding service providers, beach observations, and desk research. It is expected that results will have strategic value to managers, developers, and entrepreneurs interested in market diversification.

\section{Discussion}

This article has introduced a selection of the best articles delivered at CMT2015. Inspection of these studies in this special double issue shows diversity in topics, geographical settings, concepts, goals, and methods. To provide a context for an appreciation of these studies, other articles from this Congress, and future research, it should be pointed out that (a) all tourism in the Anthropocene is driven by humans and their increasingly sophisticated and potent technologies, (b) a great many tourism problems are complicated and characterized not only as social problems, but as wicked or super wicked problems, and (c) tourism scientists and other experts have a responsibility to be clear about the role they play in communicating results to policymakers, and they should be aware of the suitability of the role of the Honest Broker.

Finally, the authors of the articles in this special double issue are congratulated for their results and also for the questions about future research agendas they will constructively provoke in readers. Bob Dylan has sagely alerted us to the fact that the answers are elusive, but before us in the winds. Researchers and others should enjoy the struggle to grasp these.

\section{Acknowledgments}

The authors express their gratitude to the sponsors and local hosts of CMT2015 — the International Coastal and Marine Tourism Society, the University of Hawaii at Mānoa College of Social Sciences, the University of Hawaii Sea Grant Program, the Hawaii Tourism Authority, the National Oceanic and Atmospheric Administration (USA), and the management and employees at the Waikoloa Beach Marriott Resort and Spa-and the people of the Big Island for their support of the Congress and their enthusiastic interest in understanding and managing coastal and marine tourism dynamics.

\section{Notes}

\footnotetext{
${ }^{1}$ James Anthony Froude was the most prolific and influential historian of Victorian England. His Oceana: Or England and Her English Colonies (1886) was a controversial endorsement of the British Empire and was based on his personal experiences in Australia, New Zealand, and America: "The object of my voyage was not only to see the colonies themselves, but to hear the views of all classes of people there on the subject in which I was principally interested" (1881, pp. v-vi).
} 
${ }^{2}$ The successes of the various CMT Congresses led to a first publication of Tourism in Marine Environments in 2004, and ultimately in the associated International Coastal and Marine Tourism Society (ICMTS; open membership: http:// www.coastalmarinetourism.org/) founded in 2012. For perspectives on the growth of the field and the best articles from the most recent CMTs, see Lück (2014); Miller et al. (2011); and Miller et al. (2013); Miller, Orams, Lück, Auyong, and Gräupl (2009).

${ }^{3}$ See, Frodeman, Mitcham, and Pielke (2003); the Human Dimensions of Natural Resource Management website (https:// my.usgs.gov/hd/); and the International Human Dimensions Programme on Global Environmental Change (http://www. ihdp.unu.edu/pages/?p=about).

${ }^{4}$ Social Problems, a leading sociological journal, first appeared in 1953. See also, Best (1989) and Spector and Kitsuse (1987).

${ }^{5}$ Pliny the Elder, an influential confidant of statesmen including Emperor Vespasian (reign 69-79 CE), naturalist, and natural philosopher-and a cousin of Pliny the Youngeralso wrote about dolphins that were friendly and playful, even showing love toward young boys, in addition to dolphins that assisted fishermen (Pliny the Elder, 1855, Book IX, Chapters 7-10). His accounts preceded those of his cousin, but were not mentioned by Pliny the Younger. One of these about the boy and dolphin of Hippo Diarrhytus is very similar in structure and outcome to that of Pliny the Younger (Pliny the Elder, 1855, Book IX, Chapter 8, pp. 371-374). For a comparison of the dolphin stories of the cousins, see Stevens (2009).

${ }^{6}$ At the urging of his colleague, Max Webber, Rittel finally refined his original formulation of wicked problems in a now famous collaborative article (Rittel \& Webber, 1973; see also Skaburskis, 2008).

${ }^{7}$ In a Danish journal of design, Rittle (1972) discussed the evolution of systems approaches to planning with this introduction: “The term 'systems analysis' means attacking problems of planning in a rational, straightforward, systematic way, characterized by a number of attitudes which a systems analyst and designer should have” (Rittel, 1972, p. 390).

${ }^{8} \mathrm{~A}$ more extended treatment of wicked problems is found in Australian Public Service Commission (2007), and Ritchey (2011).

${ }^{9}$ In addition, of course, each option has tradeoffs where some stakeholders will be advantaged while others will be disadvantaged.

${ }^{10}$ Jasanoff (2008) characterizes the elite conflict perspective as "guided democracy” (p. 241).

${ }^{11}$ Article, poster, and workshop abstracts are available in Proceedings of CMT2015: The 8th International Congress on Coastal and Marine Tourism (http://socialsciences.hawaii. edu/conference/cmt2015/CMT-2015-Proceedings.pdf)

\section{Biographical Notes}

Marc L. Miller is Professor of Marine and Environmental Affairs at the University of Washington. His research has concerned social change, globalization, governance in the coastal zone, sustainable development, marine protected areas and destinations, iconic national parks, fish and wildlife conservation, and tourism-fisheries interactions.

Jan Auyong served for many years as Assistant Director of the Oregon Agricultural Experiment Station, Executive Associate Director of the Sun Grant Western Regional Center, and Assistant Director or Oregon Sea Grant, all housed at Oregon State University in Corvallis, Oregon. A coastal resident of Oregon, she is a strong advocate of interdisciplinary studies and communication/outreach initiatives, and has a continuing interest in the intersections of tourism, fisheries, coastal zone management, and sustainable economic development issues.

Brian W. Szuster is Associate Professor in the Department of Geography at the University of Hawaii at Mānoa. His research is focused on topics such as marine tourism, coastal development, environmental impact assessment, shrimp aquaculture, and marine spatial planning in Thailand and Hawaii.

Mark D. Needham is Professor in the Department of Forest Ecosystems and Society, and Director of the Natural Resources, Tourism, and Recreation (NATURE) Studies Laboratory at Oregon State University. In addition, he serves as Editor of the journal Human Dimensions of Wildlife. His research features applications of survey research and multivariate statistical analysis to the human dimensions of recreation, tourism, and natural resources (e.g., wildlife, forests, marine areas, coastal settings).

Mark B. Orams is Associate Dean and AUT Millennium Professor and Head of Sport and Recreation at Auckland University of Technology in New Zealand. He has widespread interests in the areas of wildlife and conservation tourism, marine ecotourism, extreme/adventure recreation and tourism, the environmental impacts of tourism and recreation, recreational sailing and surfing technologies, high performance sport, sport and exercise science, and outdoor education.

Jeff Wilks is Managing Director of Marine Tourism Australia, a company specializing in travel health, safety, and security. Dr. Wilks is a qualified lawyer, a health psychologist, and is Adjunct Professor of Health at Griffith University in Queensland, Australia. He has worked as a scuba diving instructor, has written extensively on marine safety, and serves as coeditor of the journal Travel Law Quarterly.

Michael Lück is Professor at the School of Hospitality and Tourism, and Associate Director of the New Zealand Tourism Research Institute, both located at Auckland University of Technology. His research interests include coastal and marine tourism, ecotourism, polar tourism, aviation, and all forms of sustainable tourism. 


\section{References}

Adams-Schoen, S. (2015). Sink or swim: In search of a model for coastal city climate resilience. Colombia Journal of Environmental Law, 40(3), 434-512.

Allen, G. M., \& Gould, E. M. (1986). Complexity, wickedness, and public forests. Journal of Forestry, 84(4), 20-23.

Arias-Maldonado, M. (2016). The Anthropocene turn: Theorizing sustainability in a postnatural age. Sustainability, 8(1), 10. https://doi.org/10.3390/su8010010

Australian Public Service. (2007). Tackling wicked problems: A public policy perspective. Canberra, Australia: Australian Public Service Commission.

Best, J. (1989). Images of issues: Typifying contemporary social problems. New York, NY: Aldine de Gruyter.

Brooks, J. J., \& Champ, P. A. (2006). Understanding the wicked nature of "unmanaged recreation” in Colorado's Front Range. Environmental Management, 38(5), 784798. https://doi.org/10.1007/s00267-005-0372-2

Bruggemann, J. H., Rodier, M., Guillaume, M. M. M., Andréfouët, S., Arfi, R., Cinner, J. E., Pichon, M., Ramahatratra, F., Rasoamanedrika, F., Zinke, J., \& McClanahan, T. R. (2012). Wicked Social-ecological problems forcing unprecedented change on the latitudinal margins of coral reefs: The case of southwest Madagascar. Ecology and Society, 17(4), 47. https://doi. org/10.5751/ES-05300-170447

Buchanan, R. (1992). Wicked problems in design thinking. Design Issues, 8(2), 5-21.

Charbonneau, A. (2012). Integrated coastal management: "Wicked" problems and "clumsy" solutions. The Arbutus Review, 3(1), 23-36.

Churchman, C. W. (1967). Guest editorial: Wicked problems. Management Science, 14(4), B141-B142.

Clark, W. C. (2007). Sustainability science: A room of its own. Proceedings of the National Academy of Sciences, 104(6), 1737-1738.

Dalby, S. (2016). Framing the Anthropocene: The good, the bad and the ugly. The Anthropocene Review, 3(1), 33-51.

D’Angella, F. F., \& Go, F. M. (2009). Tale of two cities' collaborative tourism marketing: Towards a theory of destination stakeholder assessment. Tourism Management, 30(3), 429-440. https://doi.org/10.1016/j.tourman. 2008.07.012

DeFries, R., \& Nagendra, H. (2017). Ecosystem management as a wicked problem. Science, 356(6335), 265-270. https://doi.org/10.1126/science.aal1950

Desmond, J. C. (2016). Afterword: Ambivalence, ambiguity and the "wicked problem" of Pacific tourism studies. In K. Alexeyeff \& J. Taylor (Eds.), Touring Pacific cultures (pp. 439-450). Acton, Australia: Australian National University Press.

Durant, R. F., \& Legge, J. S. (2006). “Wicked problems,” public policy, and administrative theory: Lessons from the GM food regulatory arena. Administration \& Society, 38(3), 309-334. https://doi.org/10.1177/0095399706289713

Ellis, E. C. (2011). Anthropogenic transformation of the terrestrial biosphere. Philosophical Transactions of the
Royal Society A: Mathematical, Physical and Engineering Sciences, 369(1938), 1010-1035. https://doi. org/10.1098/rsta.2010.0331

Farsari, I., Butler, R. W., \& Szivas, E. (2011). Complexity in tourism policies. Annals of Tourism Research, 38(3), 1110-1134. https://doi.org/10.1016/j.annals.2011.03.007

FitzGibbon, J., \& Mensah, K. O. (2012). Climate change as a wicked problem: An evaluation of the institutional context for rural water management in Ghana. Sage Open, 2(2).

Frodeman, R., Mitcham, C., \& Pielke Jr., R. (2003). Humanities for policy - and a policy for the humanities. Issues in Science and Technology, 20(1), 29-32.

Froude, J. A. (1881). Reminiscences of the High Church revival. In D. Macleod (Ed.), Good words for 1881 (pp. 18-23). London, UK: Ibister and Company.

Froude, J. A. (1886). Oceana or England and her colonies. London, UK: Longmans, Green and Company.

Fuller, R. C., \& Myers, R. R. (1941). The natural history of a social problem. American Sociological Review, 6(3), 320-329. https://doi.org/10.2307/2086189

Grint, K. (2008). Wicked problems and messy solutions: The role of leadership. Clinical Leader, I(2), 1757-3424.

Head, B. W. (2008). Wicked problems in public policy. Public Policy, 3(2), 101-118.

Jasanoff, S. (2008). Speaking honestly to power. American Scientist, 96(3), 240-243.

Lazarus, R. J. (2009). Super wicked problems and climate change: Restraining the present to liberate the future. Cornell Law Review, 94, 1153.

Levin, K., Cashore, B., Bernstein, S., \& Auld, G. (2012). Overcoming the tragedy of super wicked problems: Constraining our future selves to ameliorate global climate change. Policy Sciences, 45(2), 123-152. https://doi. org/10.1007/s11077-012-9151-0

Lück, M. (2014). Editorial: Ten years of Tourism in Marine Environments. Tourism in Marine Environments, 10(1), 1-3. https://doi.org/10.3727/154427314X14056884441581

Miller, M. L., Auyong, J., Lück, M., Orams, M., Myles, P. B., \& Wilks, J. (2011). A field engages: Papers from the 6th International Coastal and Marine Tourism Congress. Tourism in Marine Environments, 7(3), 99-112. https://doi.org/10.3727/154427311X13195453162570

Miller, M. L., Auyong, J., Smeenge, M., Offringa, B., Myles, P. B., \& Lück, M. (2013). A field focuses on destinations: Papers from the 7th International Coastal and Marine Tourism Congress. Tourism in Marine Environments, 9(3), 117-128. https://doi.org/10.3727/154427313X138 18453739350

Miller, M. L., Orams, M. B., Lück, M., Auyong, J., \& Gräupl, A. (2009). A field taking shape: Papers from the 5th International Coastal and Marine Tourism Conference. Tourism in Marine Environments, 5(2-3), 75-87.

Moser, S. C., Jeffress Williams, S., \& Boesch, D. F. (2012). Wicked challenges at land's end: Managing coastal vulnerability under climate change. Annual Review of Environment and Resources, 37(1), 51-78. https://doi. org/10.1146/annurev-environ-021611-135158 
Odeh, M. (2010). The wicked problem of tourism: Economic benefits versus socio-cultural impacts. WIT Transactions on Ecology and the Environment, 139, 345-358. https:// doi.org/10.2495/ST100301

Ogulin, R., Selen, W., \& Houghton, L. (2016). Coordination in a tourism ecosystem: Methods to tackle wicked problems. Emergence: Complexity and Organization, 18(1). https://doi.org/10.emerg/10.17357.1f1e70d186bad562e6 56d3e1d25c3887

Pielke Jr., R. A. (2007). The honest broker: Making sense of science in policy and politics. Cambridge, UK: Cambridge University Press.

Pielke Jr., R. A. (2015). Five modes of science engagement. Retrieved September 18 from http://rogerpielkejr.blog spot.com/2015/01/five-modes-of-science-engagement. html

Pliny the Elder. (1855). The natural history of Pliny (Vol. 2) (Henry T. Riley, Trans.). London, UK: Henry G. Bohn. Retrieved from http://archive.org/details/naturalhistory of21855plin

Pliny the Younger. (1969). The letters of the younger Pliny. Harmondsworth, UK and Baltimore, MD: Penguin Books.

Ritchey, T. (2011). Wicked problems—social messes. Berlin, Germany: Springer. https://doi.org/10.1007/978-3-64219653-9

Ritchey, T. (2013). Wicked problems: Modelling social messes with morphological analysis. Acta Morphologica Generalis, 2(1), 1-8.

Rittel, H. (1972). On the planning crisis: Systems analysis of the "first and second generations." Besdriftsøkonmen, 8, 390-396.

Rittel, H. W., \& Webber, M. M. (1973). Dilemmas in a general theory of planning. Policy Sciences, 4(2), 155-169.

Scherrer, P., \& Doohan, K. (2014). Taming wicked problems: Towards a resolution of tourism access to traditional owner lands in the Kimberley region, Australia. Journal of Sustainable Tourism, 22(7), 1003-1022.

Schweinsberg, S., Darcy, S., \& Cheng, M. (2017). The agenda setting power of news media in framing the future role of tourism in protected areas. Tourism Management, 62, 241-252. https://doi.org/10.1016/j.tourman.2017.04.011

Shannon, C., Oncescu, J., \& Hutchinson, S. (2016). The potential of leisure education to address the "wicked problems” prioritized in a framework for recreation in Canada. Leisure/Loisir, 40(3), 253-270. https://doi.org/ 10.1080/14927713.2016.1252937

Shindler, B. (1999). Shifting public values for forest management: Making sense of wicked problems. Western Journal of Applied Forestry, 14(1), 28-34.

Skaburskis, A. (2008). The origin of "wicked problems." Planning Theory \& Practice, 9(2), 277-280. https://doi. org/10.1080/14649350802041654

Spector, M., \& Kitsuse, J. I. (1987). Constructing social problems. New York, NY: Aldine de Gruyter.

Stevens, B. (2009). Pliny and the dolphin—or a story about storytelling. Arethusa, 42(2), 161-179. https://doi.org/10. 1353/are.0.0021
Stokes, D. E. (1997). Pasteur's quadrant: Basic science and technological innovation. Washington, DC: Brookings Institution Press.

Strickland-Munro, J. K., Allison, H. E., \& Moore, S. A. (2010). Using resilience concepts to investigate the impacts of protected area tourism on communities. Annals of Tourism Research, 37(2), 499-519. https://doi.org/10.1016/j. annals.2009.11.001

Tribe, J., \& Liburd, J. J. (2016). The tourism knowledge system. Annals of Tourism Research, 57, 44-61. https://doi. org/10.1016/j.annals.2015.11.011

Tyrrell, T. (2011). Anthropogenic modification of the oceans. Philosophical Transactions of the Royal Society A: Mathematical, Physical and Engineering Sciences, 369(1938), 887-908. https://doi.org/10.1098/rsta.2010. 0334

Van Epp, M., M., \& Garside, B. (2016). Solving “wicked” problems: Can social learning catalyse adaptive responses to climate change? IIED Working Paper, London, UK. Retrieved from https://cgspace.cgiar.org/han dle/10568/78417

Waddock, S. (2013). The wicked problems of global sustainability need wicked (good) leaders and wicked (good) collaborative solutions. Journal of Management for Global Sustainability, 1(1), 91-111.

Waters, C. N., Zalasiewicz, J., Summerhayes, C., Barnosky, A. D., Poirier, C., Gauszka, A., . . . Wolfe, A. P. (2016). The Anthropocene is functionally and stratigraphically distinct from the Holocene. Science, 351(6269), aad2622aad2622. https://doi.org/10.1126/science.aad2622

Whyte, K. P., \& Thompson, P. B. (2012). Ideas for how to take wicked problems seriously. Journal of Agricultural and Environmental Ethics, 25(4), 441-445. https://oi. org/10.1007/s10806-011-9348-9

Xiang, W.-N. (2013). Working with wicked problems in socio-ecological systems: Awareness, acceptance, and adaptation. Landscape and Urban Planning, 110, 1-4. https://doi.org/10.1016/j.landurbplan.2012.11.006

Zalasiewicz, J., Waters, C. N., Williams, M., Barnosky, A. D., Cearreta, A., Crutzen, P., . . Oreskes, N. (2015). When did the Anthropocene begin? A mid-twentieth century boundary level is stratigraphically optimal. Quaternary International, 383, 196-203.

Zalasiewicz, J., Williams, M., Haywood, A., \& Ellis, M. (2011). The Anthropocene: A new epoch of geological time? Philosophical Transactions of the Royal Society A: Mathematical, Physical and Engineering Sciences, 369(1938), 835-841. https://doi.org/10.1098/rsta.2010. 0339

Zellner, M., \& Campbell, S. D. (2015). Planning for deeprooted problems: What can we learn from aligning complex systems and wicked problems? Planning Theory \& Practice, 16(4), 457-478. https://doi.org/10.1080/14649 357.2015.1084360 
Copyright of Tourism in Marine Environments is the property of Cognizant, LLC and its content may not be copied or emailed to multiple sites or posted to a listserv without the copyright holder's express written permission. However, users may print, download, or email articles for individual use. 